\title{
Levels of ochratoxin A in serum from urban and rural Portuguese populations and estimation of exposure degree
}

\author{
C.M. Lino *, M.L. Baeta, M. Henri, A.M.P. Dinis, A.S. Pena, M.I.N. Silveira \\ Group of Bromatology - CEF, Faculty of Pharmacy, University of Coimbra, 3000-Coimbra, Portugal
}

Received 18 December 2006; accepted 13 October 2007

\begin{abstract}
Urban and rural population exposure to ochratoxin A (OTA) in central zone of Portugal was investigated in three places: Coimbra, Verride and Ereira.

The analytical method proposed for the determination of ochratoxin A involved extraction with chloroform-orthophosphoric acid, cleanup through an immunoaffinity column (IAC), high performance liquid chromatography (HPLC) with spectrofluorimetric detection (FD) for separation and identification of ochratoxin A, and confirmation with HPLC-FD after OTA methylation in serum. The limit of quantification of the proposed method was $0.1 \mu \mathrm{g} / \mathrm{L}$ for serum and $0.05 \mu \mathrm{g} / \mathrm{L}$ for blood. OTA recoveries in serum ranged from $70.3 \%$ to $115.3 \%$ for levels at $0.25 \mu \mathrm{g} / \mathrm{L}$ and $0.5 \mu \mathrm{g} / \mathrm{L}$, respectively, with a within-day RSD between $8.0 \%$ and $16.2 \%$.

Ochratoxin A serum levels were evaluated in an hundred and four donors from Coimbra city, Verride, and Ereira. The study revealed a frequency of detection of $100 \%$. The ratio of ochratoxin A level in serum to whole blood was $2.0 \pm 0.7$.

The overall concentrations range from 0.25 to $2.49 \mu \mathrm{g} / \mathrm{L}, 0.14$ to $1.91 \mu \mathrm{g} / \mathrm{L}$, and 0.19 to $0.96 \mu \mathrm{g} / \mathrm{L}$, for samples of Verride, Ereira, and Coimbra, respectively. The mean concentration and standard deviation were $0.78 \pm 0.53 \mu \mathrm{g} / \mathrm{L}, 0.44 \pm 0.31 \mu \mathrm{g} / \mathrm{L}$, and $0.42 \pm 0.18 \mu \mathrm{g} / \mathrm{L}$ for the same samples. A significant difference was found in Verride population $(P$-value $=0.000)$.

Levels of OTA are clearly higher in males from rural areas than in females. For all samples, a significant difference was found in Verride male population $(P$-value $=0.014)$.
\end{abstract}

(c) 2007 Elsevier Ltd. All rights reserved.

Keywords: Ochratoxin A; Serum; Portugal; HPLC; Spectrofluorimeter detection

\section{Introduction}

Ochratoxin A (OTA) is a mycotoxin produced by several Aspergillus and Penicillium species. Among Aspergillus species there are two in section Nigri and four in section Circumdati, formerly the Aspergillus ochraceus group, now referred to as Aspergillus alutaceus (Thuvander et al., 2001; Marquardt and Frolich, 1992; Zimmerli and Dick, 1995; Valenta, 1998). The presence of OTA in human blood or serum is related to the ingestion of several contaminated food. Penicillium verrucosum has been consistently associated with cereals, Aspergillus species with

\footnotetext{
* Corresponding author. Tel.: +351 239859994; fax: +351 239827126.

E-mail address: cmlino@ci.uc.pt (C.M. Lino).
}

coffee beans, and Aspergillus niger and carbonarius have been isolated from dried vine fruit (Thuvander et al., 2001; Pena et al., 2005). Other food items are also contaminated, cow's and human milk (Zimmerli and Dick, 1995; Valenta, 1998; Breitholtz-Emanuelson et al., 1993), animal tissues, muscle, and organs, eggs (Marquardt and Frolich, 1992; Valenta, 1998; Moreno Guillamont et al., 2005), pulses, wine and beer (Thuvander et al., 2001; Castellari et al., 2000; Visconti et al., 2000; Leitner et al., 2002).

Recognized as carcinogenic, teratogenic, immunotoxic, genotoxic, as well nephrotoxic (Thuvander et al., 2001; Marquardt and Frolich, 1992; Zimmerli and Dick, 1995; Valenta, 1998; Leitner et al., 2002), the evaluation of OTA levels in different types of populations is unquestionable to provide data on exposure and evaluate the possible human health risk to OTA. 
When ingested as a food contaminant, OTA is frequently found in human blood due to the long elimination half-life (about 35 days in serum), as consequence of its binding to plasma proteins, its enterohepatic circulation and its re-absorption from urine. This renders OTA among the most frequent mycotoxins contaminants found in human blood all over the world (Pena et al., 2006).

Several studies carried out in Europe (Zimmerli and Dick, 1995; Peraica et al., 1999, 2001; Jimenez et al., 1998), Africa (Kane et al., 1991; Singare-Tigori et al., 2006), Asia (Assaf et al., 2004) and Canada (Scott et al., 1998) report the presence of OTA in human serum or plasma, clearly demonstrating the human exposure to this mycotoxin. Investigations on OTA occurrence in different countries have shown that it occurs in their populations with different mean concentrations in plasma or serum. These levels oscillated between $0.18 \mu \mathrm{g} / \mathrm{L}$, in Norway, and $1.09 \mu \mathrm{g} / \mathrm{L}$, in United Kingdom (Thuvander et al., 2001). In most countries, the detection frequency is $100 \%$ (Thuvander et al., 2001; Zimmerli and Dick, 1995) with exception of Yugoslavia, Germany, and Croatia, with $6.6 \%, 98 \%$, and 59.4\%, respectively (Marquardt and Frolich, 1992; Gareis et al., 2001; Peraica et al., 1999).

The aim of this work was to validate a high performance liquid chromatography with spectrofluorimetric detection (HPLC-FD) method for the determination of ochratoxin A levels in blood and serum, and assess the correlation factor between the OTA levels in serum and in whole blood. The method was applied to quantify the levels and the frequency of detection in twenty blood samples and 104 serum samples of different types of populations from central zone of Portugal, urban and rural, in order to evaluate its exposure degree.

\section{Experimental}

\subsection{Solvents and materials}

HPLC grade acetonitrile, chloroform, toluene, and methanol were purchased from Carlo Erba (Milan, Italy). Acetic acid, hydrochloride acid, sodium hydroxide, potassium chloride, potassium dihydrogenphosphate, anhydrous disodium hydrogenphosphate, sodium chloride, and $85 \%$ orthophosphoric acid were obtained from Merck (Darmstadt, Germany). Water was purified by distillation and passage through a Milli-Q system (Millipore, Bedford, MA, USA). OTA with purity grade $\geqslant 98 \%$, and boron trifluoride $14 \%$ methanolic solution were purchased from Sigma Chemical Co. (St. Louis, MO, USA).

Immunoaffinity columns (IAC) Ochratest ${ }^{\mathrm{TM}}$ were from VICAM (Watertown, USA), centrifuge Meditronic S-599 from Selecta (Barcelona, Spain), vortex mixer from Retsh (Haan, Germany), and ultrasonic bath RK 100 from Sonorex (Berlin, Germany).

\subsection{HPLC system and chromatographic conditions}

The HPLC system consisted of a pump, model 307 (Gilson Medical Electronics, France), an $20 \mu \mathrm{L}$ injection valve, model 7125 (Rheodyne, Cotati, California, USA), a guard column, $\mathrm{C}_{18}-5 \mu \mathrm{m}$ Nucleosil $120 \mathrm{KS}$ $\left(30 \times 4 \mathrm{~mm}\right.$ i.d.), and a column, $\mathrm{C}_{18}-5 \mu \mathrm{m}$ Nucleosil $100 \mathrm{KS}$ $(250 \times 4.6 \mathrm{~mm}$ i.d.). A spectrofluorimeter, model LS-3B (Perkin-Elmer, USA), was connected to the HPLC. The analyses were made using $333 \mathrm{~nm}$ for excitation and $460 \mathrm{~nm}$ for emission. An integrator, model 3390A (Hewlett-Packard, Philadelphia, USA), was used to measure peak areas.

The mobile phase consisted of a mixture of water:acetonitrile:glacial acetic acid (49.5:49.5:1.0 v/v/v) and the flow rate was $1 \mathrm{~mL} / \mathrm{min}$.

\subsection{Extraction and clean-up}

Two $\mathrm{mL}$ of whole blood or serum were added of $10 \mathrm{~mL}$ of a solution containing $33.7 \mathrm{~mL}$ of $85 \%$ orthophosphoric acid and $118 \mathrm{~g}$ sodium chloride per liter, and mixed for $1 \mathrm{~min}$. After, $2 \times 5 \mathrm{~mL}$ of chloroform were added and intensively mixed for $3 \mathrm{~min}$, and then centrifuged at $2500 \mathrm{~g}$, $15 \mathrm{~min}$. The organic phase was evaporated to dryness at $30-40{ }^{\circ} \mathrm{C}$. The dry extract was dissolved in $3 \times 5 \mathrm{~mL}$ of PBS-methanol and passed through an IAC column. After the solution had passed through the column, the column was washed with water and dried by air. OTA was eluted with $3 \mathrm{~mL}$ methanol and the eluate evaporated at $30-40{ }^{\circ} \mathrm{C}$ under a gentle stream of nitrogen. The residue was dissolved in $250 \mu \mathrm{L}$ of mobile phase and injected in the HPLC system.

\subsection{Validation studies}

Linearity was evaluated in the range of $0.1-0.5 \mathrm{ng}(5-25 \mu \mathrm{g} / \mathrm{L})$. For calibration curve, the stock solution was prepared at $5 \mu \mathrm{g} / \mathrm{mL}$ in toluene:acetic acid (99:1). Standard solution was prepared by evaporating $10 \mu \mathrm{L}$ of stock solution at dryness, and diluting to $10 \mathrm{~mL}$ with mobile phase. Work solutions were prepared by dissolving standard solutions in mobile phase.

For fortification assays, the stock solution was prepared at $250 \mu \mathrm{g} / \mathrm{mL}$ in toluene:acetic acid (99:1). Standard solution was prepared at $10 \mu \mathrm{g} / \mathrm{mL}$, and the work solution at $1 \mu \mathrm{g} / \mathrm{mL}$. The recovery studies were made by adding OTA solution prepared in toluene: acetic acid (99:1) to three replicates of each one of the matrix involved in this study (Table 1).

\subsection{Sampling and description of populations}

The present study was carried out in 2002 in the central region of Portugal, in the neighbourhood of Coimbra, the most important city of this region, placed between Lisbon and Oporto. Samples were collected in Coimbra city and two farming villages, Verride and Ereira, which are located in the Mondego valley, about $30 \mathrm{~km}$ from Coimbra. Verride is on the left bank at a higher level as opposed of Ereira which stays on the right bank at river level.

All volunteers were asked to complete a rapid questionnaire about age, clinical history, and occupation.

Blood samples from an hundred four donors from these three populations were collected. Blood samples of Coimbra donors were collected at the Laboratory of Clinical Analysis of Faculty of Pharmacy, University of Coimbra, from May to July 2002. Donors were aged between 21 and 57 $(31 \pm 10.7)$. Blood samples of Verride and Ereira donors were collected at the respective Health Centers, from October to December 2001, and from December 2001 to January 2002, respectively. In the first village, the donor age varied between 26 and 92 (76 \pm 10.9$)$, and in the last one, it oscillated from 19 to $88(59 \pm 15.1)$. Mean weights were $69 \pm 13.7,73 \pm 10.9$, and $69 \pm 11.3$, for Coimbra, Verride and Ereira donors, respectively. The study included 29 samples from Coimbra (16 women and 13 men), 31 from Verride (17 women and 14 men), and 44 from Ereira (34 women and 10 men).

Table 1

Accuracy and precision of analytical methodology for human whole blood and serum

\begin{tabular}{lcc}
\hline Fortification $(\mu \mathrm{g} / \mathrm{L})$ & Whole blood $\mathrm{R} \pm \mathrm{SD}^{*}(\%)$ & Serum $\mathrm{R} \pm \mathrm{SD}^{*}(\%)$ \\
\hline 0.25 & $114.3 \pm 22.9$ & $70.3 \pm 16.2$ \\
0.5 & $82.1 \pm 20.6$ & $115.3 \pm 13.1$ \\
1.25 & $98.3 \pm 13.3$ & $88.0 \pm 8.0$ \\
2.0 & $74.3 \pm 10.6$ & $95.7 \pm 8.1$ \\
${ }^{*} n=3$. &
\end{tabular}

${ }^{*} n=3$. 
Samples were collected in glass tubes $(50 \mathrm{~mL})$, in order to obtain the serum samples, or in $3 \mathrm{~mL}$ plastic tubes containing ethylenediaminetetracetic acid for whole blood samples. Serum was obtained by heating the tubes at $37^{\circ} \mathrm{C}$ for $3 \mathrm{~h}$, and submitting it to centrifugation at $1500 \mathrm{~g}$ for $10 \mathrm{~min}$.

\subsection{Chemical confirmation}

The first confirmation was performed according to the method of Zimmerli and Dick (1995): $200 \mu \mathrm{L}$ of the extract was diluted to $2.5 \mathrm{ml}$ with methanol and $0.1 \mathrm{~mL}$ of $37 \%$ concentrated $\mathrm{HCl}$ was added. After standing overnight at room temperature, the methanol was evaporated and the residue dissolved in $250 \mu \mathrm{L}$ of the mobile phase.

Another confirmation was carried out by following the procedure of Castegnaro et al. (1998). In this way, sample extracts were evaporated to dryness, $150 \mu \mathrm{L}$ BF3 (14\% methanolic solution) were added, and the mixture was left at $60{ }^{\circ} \mathrm{C}$ for $10 \mathrm{~min}$. After evaporation, the residue was dissolved in $150 \mu \mathrm{L}$ water-acetonitrile-glacial acetic acid (49.5:49.5:1.0). The OTA methyl esters were analyzed according to the HPLC method described earlier.

\subsection{Statistical analysis}

Database management and statistical analysis were performed with the SPSS 10.0 Microsoft version. The differences in the OTA levels between different populations were tested with the Kruskal-Wallis test. $P \leqslant 0.05$ (two-tailed) was considered to be statistically significant.

\section{Results}

\subsection{Analytical method validation}

The calibration curve was obtained using the linear least-squares regression procedure of the peak area versus the concentration. The correlation coefficient $\left(r^{2}\right)$ was 0.9914 in the range of $0.1-0.5 \mathrm{ng}(5-25 \mu \mathrm{g} / \mathrm{L})$.

For whole blood and serum matrices, accuracy and precision of the analytical methodology were adequate for all the fortification levels evaluated (Table 1) and according to international parameters (Hubner, 1998; Hill and Reynolds, 1999; Swartz and Krull, 1998) The recovery, for whole blood, varied between $74.3 \%$ to $114.3 \%$, for levels at $2 \mu \mathrm{g} / \mathrm{L}$ and $0.25 \mu \mathrm{g} / \mathrm{L}$, and the precision oscillated between $10.6 \%$ to $22.9 \%$ for levels at $2 \mu \mathrm{g} / \mathrm{L}$ and $0.25 \mu \mathrm{g} /$ $\mathrm{L}$. For the serum matrix, the recovery varied between $70.3 \%$ to $115.3 \%$, for levels at $0.25 \mu \mathrm{g} / \mathrm{L}$ and $0.5 \mu \mathrm{g} / \mathrm{L}$, and the precision oscillated between $8.0 \%$ to $16.2 \%$ for levels at $1.25 \mu \mathrm{g} / \mathrm{L}$ and $0.25 \mu \mathrm{g} / \mathrm{L}$. Fig. 1 shows the HPLC-FD chromatograms of the OTA standard, one serum sample, and one fortified serum sample.

The limit of quantification (LOQ) was determined by the signal-to-noise ratio approach, defined as that level resulting in a signal-to-noise ratio of approximately 10:1. For serum matrix, the limit of quantification was $0.1 \mu \mathrm{g} / \mathrm{L}$, and for whole blood $0.05 \mu \mathrm{g} / \mathrm{L}$.

\subsection{Confirmation by methylation with boron trifluoride}

For confirmation, OTA was converted into OTA methyl ester and two different procedures were evaluated. Positive confirmation was based on the disappearance of the OTA

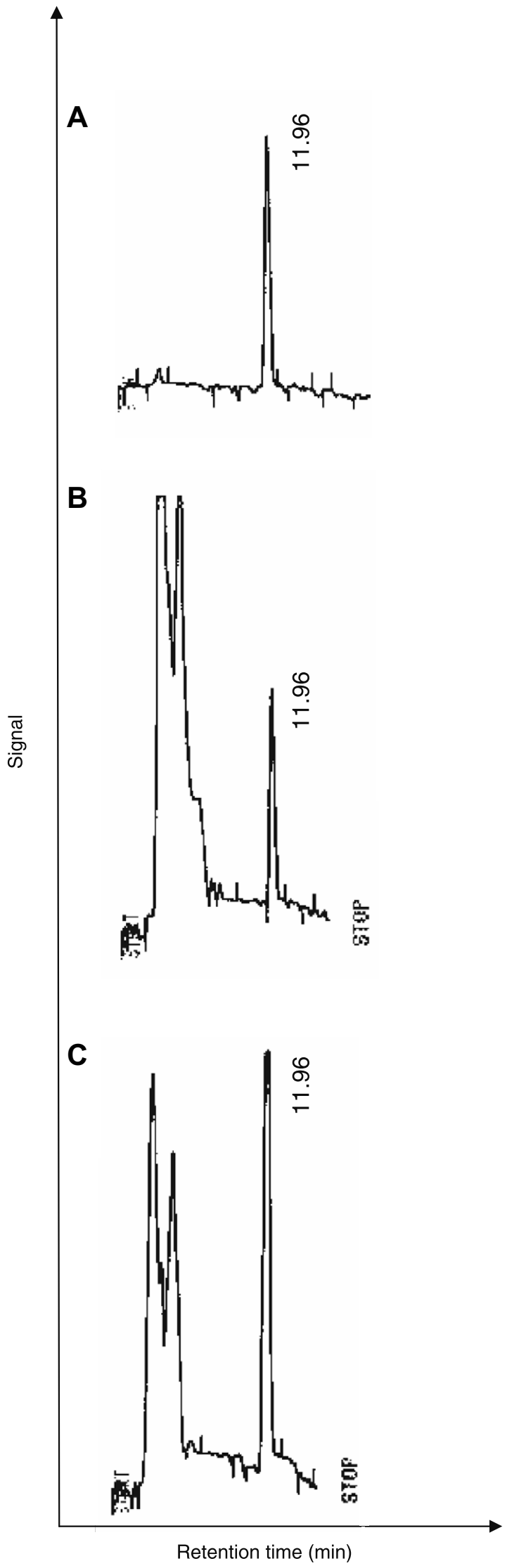

Fig. 1. Chromatograms of OTA standard (A) (2.5 ng) (retention time 11.96), one sample containing $0.496 \mu \mathrm{g} / \mathrm{L}$ (B), and one serum sample spiked at $1.25 \mu \mathrm{g} / \mathrm{L}(\mathrm{C})$. 
peak and the appearance of a new one, corresponding to OTA methyl ester, at a retention time of $21.3 \mathrm{~min}$. The recovery rate of the methyl ester was higher, 93\%, for boron trifluoride-methanol solution when compared with the rate obtained when the method of Zimmerli and Dick (1995) was used, 79\%, with good blanks, in spite of the appearance of one peak with a different retention time, which did not interfere. For these reasons, the confirmation of OTA in samples was performed according to the first method.

\subsection{Relation between OTA levels in serum and blood}

To establish the mean ratio of ochratoxin A level in serum to whole blood, twenty samples were available. The obtained ratio was $2.0 \pm 0.7$ (Fig. 2). This value agrees with the ratio of $2.0 \pm 0.1$, obtained when 3 samples of human blood and serum were analyzed, with the ratio $1.9 \pm 0.1$ achieved with 15 samples of pigs, or 1.7 obtained with rats (Zimmerli and Dick, 1995).

\subsection{Evaluation of OTA in serum samples}

For the evaluation of the OTA levels, the serum matrix was chosen, once higher OTA levels and cleaner extracts were obtained. A total of 104 samples of serum were analyzed under the described conditions and the frequency of detection was $100 \%$, at concentrations ranging between 0.14 and $2.49 \mu \mathrm{g} / \mathrm{L}$.

The present study shows that the percentage of OTA containing samples with levels higher than $2 \mu \mathrm{g} / \mathrm{L}$ was only $0.96 \%$, being $2.49 \mu \mathrm{g} / \mathrm{L}$ the highest level.

Table 2 shows minimum and maximum levels, mean concentration and standard deviation (SD) of OTA in

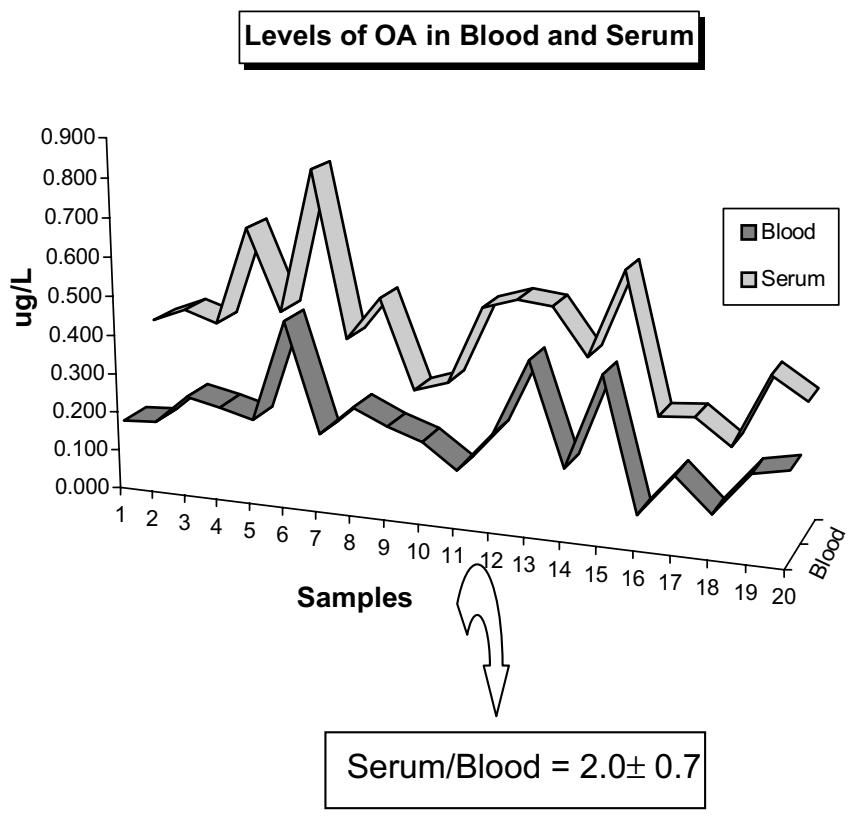

Fig. 2. Mean ratio of OTA levels in both matrices.
Table 2

Minimum, maximum, mean concentration of serum, and SD of OTA $(\mu \mathrm{g} /$ L) in inhabitants of three places in central zone of Portugal

\begin{tabular}{llll}
\hline & Coimbra & Verride & Ereira \\
\hline Min & 0.19 & 0.25 & 0.14 \\
Max & 0.96 & 2.49 & 1.91 \\
Mean & 0.42 & 0.78 & 0.44 \\
Std. Dev. & 0.18 & 0.53 & 0.31 \\
\hline
\end{tabular}

Table 3

Mean concentration $(\mu \mathrm{g} / \mathrm{L})$ and SD of OTA in women $(\mathrm{W})$ and men $(\mathrm{M})$ serum in the three places

\begin{tabular}{|c|c|c|c|c|c|c|}
\hline & $\begin{array}{l}\text { Coimbra- } \\
\mathrm{W}\end{array}$ & $\begin{array}{l}\text { Verride- } \\
\mathrm{W}\end{array}$ & $\begin{array}{l}\text { Ereira- } \\
\mathrm{W}\end{array}$ & $\begin{array}{l}\text { Coimbra- } \\
\mathrm{M}\end{array}$ & $\begin{array}{l}\text { Verride- } \\
\mathrm{M}\end{array}$ & $\begin{array}{l}\text { Ereira- } \\
\mathrm{M}\end{array}$ \\
\hline Mea & 0.38 & 0.60 & 0.40 & 0.46 & 1.01 & 0.55 \\
\hline $\begin{array}{l}\text { Std. } \\
\text { Dev }\end{array}$ & 0.15 & 0.21 & 0.30 & 0.21 & 0.62 & 0.34 \\
\hline
\end{tabular}

serum of the inhabitants of three places of the central zone of Portugal. The overall concentrations range from 0.25 to $2.49 \mu \mathrm{g} / \mathrm{L}, 0.14$ to $1.91 \mu \mathrm{g} / \mathrm{L}$, and 0.19 to $0.96 \mu \mathrm{g} / \mathrm{L}$, for samples of Verride, Ereira, and Coimbra, respectively. The mean concentration and standard deviation were $0.78 \pm 0.53 \mu \mathrm{g} / \mathrm{L}, 0.44 \pm 0.31 \mu \mathrm{g} / \mathrm{L}$, and $0.42 \pm 0.18 \mu \mathrm{g} / \mathrm{L}$ for the same samples. A significant difference was found in Verride population $(P$-value $=0.000)$.

Mean concentration and SD of OTA in women (W) and men (M) serum in the three places are shown in Table 3. Levels of OTA are clearly higher in males of rural areas than in females, but this statement was not so clear in Coimbra. For all samples, a significant difference was found only in Verride male population $(P$ value $=0.014)$.

For women, the mean concentration and standard deviation were $0.6 \pm 0.21 \mu \mathrm{g} / \mathrm{L}, \quad 0.40 \pm 0.30 \mu \mathrm{g} / \mathrm{L}$, and $0.38 \pm 0.15 \mu \mathrm{g} / \mathrm{L}$ for samples of Verride, Ereira, and Coimbra, respectively. A significant difference was only found in Verride females $(P$ value $=0.002)$.

For men, the mean concentration and standard deviation was $1.01 \pm 0.62 \mu \mathrm{g} / \mathrm{L}, \quad 0.55 \pm 0.34 \mu \mathrm{g} / \mathrm{L}$, and $0.46 \pm 0.21 \mu \mathrm{g} / \mathrm{L}$ for the same samples. The samples of the two villages showed higher levels, especially those from Verride, than those from the Coimbra city. A significant difference was found in Verride males ( $P$ value $=0.027$ ). No statistical differences were observed between sexes within each one of the three studied populations (Verride: $P$ value $=0.088$, Ereira: $P$-value $=0.161$, and Coimbra $P$-value $=0.346$ ).

\subsection{Evaluation of daily intake}

In the studied populations, the estimated daily intake (EDI), based on the equation of Breitholtz et al. (1991), was $0.56 \mathrm{ng} / \mathrm{kg}$ b.w. per day in Coimbra (range 0.26 $1.29 \mathrm{ng} / \mathrm{kg}$ b.w. per day), $0.59 \mathrm{ng} / \mathrm{kg}$ b.w. per day in Ereira (range $0.19-2.56 \mathrm{ng} / \mathrm{kg}$ b.w. per day), and $1.05 \mathrm{ng} / \mathrm{kg} \mathrm{b.w}$. per day in Verride (range $0.34-3.35 \mathrm{ng} / \mathrm{kg}$ b.w. per day). 


\section{Discussion}

The percentage of OTA containing samples with levels higher than $2 \mu \mathrm{g} / \mathrm{L}$ differs from those of some countries. In Spain, $5 \%$ of samples have levels above $2 \mu \mathrm{g} / \mathrm{L}$, and in France, in Alsace, Aquitaine, and Rhône-Alpe rural areas, $2.6 \%, 10 \%$, and $0.3 \%$ of samples had levels above $2 \mu \mathrm{g} / \mathrm{L}$, respectively. In Spain, in Italy, and in France (Aquitaine area), the maximum values were $4 \mu \mathrm{g} / \mathrm{L}, 2 \mu \mathrm{g} / \mathrm{L}$ and $161 \mu \mathrm{g} / \mathrm{L}$, respectively (Jimenez et al., 1998; Creppy et al., 1993). The German population presents a median concentration of $0.2 \mu \mathrm{g} / \mathrm{L}$ (Gareis et al., 2001). Higher maximum levels have also been reported in other European countries, such as Croatia, Denmark, and Poland (Peraica et al., 1999; Jimenez et al., 1998) (Table 4). In Canada, the high- est value was $2.37 \mu \mathrm{g} / \mathrm{L}$, and only 3 of 144 samples exceeded $2 \mu \mathrm{g} / \mathrm{L}$ (Scott et al., 1998).

The occurrence of higher levels in rural populations may be related with different situations. One important factor is due to the climate difference between the studied zones. Verride and Ereira located in the Mondego valley present a higher moisture grade, what probably contributes for deficient procedures of conservation of cereals and other food items. The highest consumption of alcoholic beverages, different consumption habits, and regional food intake patterns may contribute to this situation. Another problem may be related to the local production of food that may influence the OTA exposure. Comparing the three populations, significant difference was found in Verride group aged between 40 and $60(P$-value $=0.005)$. Also, a

Table 4

Ochratoxin A in serum or plasma samples in some countries

\begin{tabular}{|c|c|c|c|c|c|}
\hline Country & $\%$ Detection & LOQ & Range & Mean & References \\
\hline Tunisia & & & & & Hassen et al. (2004) \\
\hline Healthy & 71 & & nd-7.5 & $2.6 \pm 2.3$ & \\
\hline CIN (chronic interstitial nephropaty) & 93 & & $17.4-140.5$ & $44.4 \pm 19$ & \\
\hline Tunisia & & 0.10 & & & Grosso et al. (2003) \\
\hline Nephrophatic patients & 99.9 & & $0.11-5.80$ & $0.99 \pm 1.28$ & \\
\hline Non-affected patients & 100 & & $0.12-8.06$ & $0.53 \pm 1.0$ & \\
\hline Bulgaria & & 0.1 & & & Petkova-Bocharova et al. (2003) \\
\hline Gorno Peshtene & 100 & & $0.2-1.6$ & $0.67 \pm 0.24$ & \\
\hline Beli Izvor & 100 & & $0.1-10.9$ & $2.01 \pm 0.54$ & \\
\hline Italy & & & & & Brera et al. (2002) \\
\hline Worker's in cocoa, coffee and spices & & & $0.94-3.28$ & & \\
\hline Italian population & & & & 0.53 & \\
\hline Italy & & & $0.12-2.84$ & 0.56 & Palli et al. (1999) \\
\hline Tuscany (Florence) & 97 & & & & \\
\hline Italy & 100 & & $0.1-2$ & 0.53 & Jimenez et al. (1998) \\
\hline Morocco & 60 & 0.4 & nd-6.59 & $0.29 \pm 0.51$ & Fillali et al. (2002) \\
\hline Lebanon & 33 & 0.6 & $0.1-0.87$ & $0.17 \pm 0.01$ & Assaf et al. (2004) \\
\hline Croatia & & & & & Peraica et al. (2001) \\
\hline Osijek & & & & 0.56 & \\
\hline Rijeka & & & & 0.13 & \\
\hline Split & & & & 0.31 & \\
\hline Vara Zdin & & & & 0.31 & \\
\hline Zagreb & & & & 0.19 & \\
\hline Croatia & 59.4 & & $0.2-15.9$ & 0.39 & Peraica et al. (1999) \\
\hline Canada & 100 & & $0.29-2.37$ & $0.88 \pm 0.35$ & Scott et al. (1998) \\
\hline Sweden & & & & & Thuvander et al. (2001) \\
\hline Visby & 29 & & $0.3-6.7$ & $0.21 \pm 0.17$ & \\
\hline Oslo & & & & $0.18 \pm 0.11$ & \\
\hline Denmark & & & & & Hald (1991) \\
\hline 1986 & & & nd-9.7 & 1.5 & \\
\hline 1987 & & & nd-9.4 & 2.3 & \\
\hline 1988 & & & nd-13.2 & 1.6 & \\
\hline Spain & 53 & & $0.5-4.0$ & 0.7 & Jimenez et al. (1998) \\
\hline France & $15-19$ & & $0.1-6$ & & Creppy et al. (1993) \\
\hline Switzerland & & & & & Zimmerli and Dick (1995) \\
\hline Alps-north & 100 & & $0.06-2.14$ & & \\
\hline Alps-south & 100 & & $0.11-6.02$ & & \\
\hline Poland & 4.2 & & $1.3-4.8$ & 0.3 & Hald (1991) \\
\hline Portugal & & 0.1 & & & This study \\
\hline Coimbra & 100 & & $0.19-0.96$ & $0.42 \pm 0.18$ & \\
\hline Ereira & 100 & & $0.14-1.91$ & $0.44 \pm 0.31$ & \\
\hline Verride & 100 & & $0.25-2.49$ & $0.78 \pm 0.53$ & \\
\hline
\end{tabular}


significant difference was found between Verride $(P$ value $=0.027$ ) and Ereira groups $71-80$ years old.

In different countries such as France (Creppy et al., 1993; Scott et al., 1998; Dragacci et al., 1999), Sweden (Zimmerli and Dick, 1995; Scott et al., 1998), Tunisia (Peraica et al., 1999; Scott et al., 1998), and in five croatian cities (Peraica et al., 2001) regional differences have also been observed.

Comparing our results with others from different countries, the levels of Coimbra inhabitants are higher than those from Sweden-Visby, Norway-Oslo (Thuvander et al., 2001) and Switzerland (Zimmerli and Dick, 1995). Those values are lower than samples from Canada, United Kingdom, and Italy. The mean concentration of Verride samples is similar to that of Canada, but lower than that of United Kingdom, Algeria, and Abidjan, Tunisia (Scott et al., 1998; Thuvander et al., 2001; Zimmerli and Dick, 1995; Singare-Tigori et al., 2006).

The frequency of detection of $100 \%$ was also observed in Sweden-Visby, Switzerland, Norway-Oslo, and Canada. However, other countries, such Yugoslavia, Germany, Croatia, and Tunisia showed detections oscillating between 6.6\% and 98\% (Marquardt and Frolich, 1992; Gareis et al., 2001; Peraica et al., 1999; Singare-Tigori et al., 2006), probably due to different limits of detection or limits of quantification of the analytical methodology used. Data disposable from bibliography shows that LODs vary between $0.01 \mu \mathrm{g} / \mathrm{L}$ and $0.52 \mu \mathrm{g} / \mathrm{L}$ and LOQs between $0.05 \mu \mathrm{g} / \mathrm{L}$ and $0.78 \mu \mathrm{g} / \mathrm{L}$ (Thuvander et al., 2001; Jimenez et al., 1998).

Comparing the OTA levels regarding gender in this study with others from different countries, we conclude that the levels found in women and men from Coimbra, and in women from Ereira are higher than those found in Sweden-Visby, Norway-Oslo (Thuvander et al., 2001), Switzerland - North and South of the Alps (Zimmerli and Dick, 1995), and Lebanon (Assaf et al., 2004). Mean concentrations of women and men from Verride and men from Ereira are higher than that of all of the referred countries, with exception for men concentrations in Switzerland - south of the Alps, whose levels are higher than Verride women and Ereira men. However, mean concentration of Verride men is the highest.

The high levels found in Verride may cause concern, once OTA is classified as possibly carcinogenic for humans (group 2B) by International Agency for Research on Cancer (1993).

The results of the EDI obtained in our study are within the range for tolerable daily intake of $0.2-4.2 \mathrm{ng} / \mathrm{kg}$ b.w. per day established by Kuiper-Goodman and Scott in 1989 (Marquardt and Frolich, 1992), and below $5 \mathrm{ng} /$ $\mathrm{kg}$ b.w., the tolerable daily intake (TDI) estimated by the Scientific Committee on Foods (SFC) of the European Union, (2002).

None of the analyzed populations exceeded those values. Although the mean daily intake of OTA in those populations, the occasional samples with very high concentrations of OTA urges strict control of OTA contamination of food and feed.

EDI values in Portuguese populations are higher than other European populations. In Germany, the EDIs for adults are in the range of $0.5-0.6 \mathrm{ng} / \mathrm{kg} \mathrm{b.w}$. (Gareis et al., 2001). In Croatian cities, the EDI was estimated to be in the range from $0.24 \mathrm{ng} / \mathrm{kg}$ b.w. per day to $0.91 \mathrm{ng} /$ $\mathrm{kg}$ b.w. per day (Peraica et al., 1999). The intake in Oslo and Visby were 0.24 and $0.28 \mathrm{ng} / \mathrm{kg}$ b.w. per day (Thuvander et al., 2001). In 1994 in Canada, the EDI was estimated as $1.2 \mathrm{ng} / \mathrm{kg}$ b.w. per day (Scott et al., 1998).

\section{Acknowledgements}

Besides the financial support of FCT and POCTI/FEDER, the authors thank to our colleague Ph.D. Fernando Ramos for his precious help in samples process acquisition. To Dr ${ }^{\mathrm{a}}$ Fátima Rodrigues, Health Centre Director of Montemor-o-Velho, to Dr ${ }^{\mathrm{a}}$ Fernanda Palma and Dr. Arriaga for giving permission for sample collection, and nurse $\mathrm{M}^{\mathrm{a}} \mathrm{Luz}$ Batista, for collecting the samples. We also would like to thank to $\operatorname{Dr}^{\mathrm{a}}$ Lucília Silveira, Isabel Alves and $\mathrm{M}^{\mathrm{a}}$ Isabel Mamede from the Laboratory of Clinical Analysis for their cooperation.

\section{References}

Assaf, H., Betbeder, A.-M., Creppy, E.E., Pallardy, M., Azouri, H., 2004 Ochratoxin A levels in human plasma and foods in Lebanon. Hum. Exper. Toxicol. 23, 495-501.

Breitholtz, A., Olsen, M., Dahlback, A., Hult, K., 1991. Plasma ochratoxin A levels in three Swedish populations surveyed using an ion-pair HPLC technique. Food Addit. Contam. 8, 183-192.

Breitholtz-Emanuelson, A., Olsen, M., Oskarsson, A., Palminger, I., Hult, K., 1993. Ochratoxin A in cow's milk and in human milk with corresponding human blood samples. J. AOAC Int. 76, 842-846.

Brera, C., Caputi, R., Miraglia, M., Iavicoli, I., Salerno, A., Carelli, G., 2002. Exposure assessment to mycotoxins in workplaces: aflatoxins and ochratoxin A occurence in airborne dusts and human sera. Microchem. J. 73, 167-173.

Castegnaro, M., Mohr, U., Pfohl-Leszkowicz, A., Estéve, J., Steinmann, J., Tillmann, T., Michelon, J., Bartsch, H., 1998. Sex-and strain specific induction of renal tumors by ochratoxin $\mathrm{A}$ in rats correlates with DNA adduction. Int. J. Cancer 77, 70-75.

Castellari, M., Fabbri, S., Fabiani, A., Amati, A., Galassi, S., 2000 Comparison of different immunoaffinity clean-up procedures for highperformance liquid chromatographic analysis of ochratoxin $\mathrm{A}$ in wines. J. Chromatogr. A 888, 129-136.

Creppy, E., Castegnaro, M., Grosse, Y., Mérieux, J., Manier, C., Moncharmont, P., Waller, C., 1993. Coloque INSERM/John Libbey Eurotext Ltd., Montrouge, France, vol. 231, pp. 147-158.

Dragacci, S., Grosso, F., Bire, R., Fremy, J.M., Coulon, S., 1999. A French monitoring programme for determining of ochratoxin A occurrence in pig kidneys. Nat. Toxins 7, 167-173.

EU, 2002. Assessment of dietary intake of ochratoxin A by the population of EU member states (report for SCOOP task 3.2.7.). <http:// europa.eu.int/comm/food/fs/scoop/index_en.html $>$.

Fillali, A., Betbeder, A.M., Baudrimont, I., Benayada, A., Soulaymani, R., Creppy, E.E., 2002. Ochratoxin A in human plasma in Morocco: a preliminary survey. Hum. Exp. Toxicol. 21, 241-245.

Gareis, M., Wolff, J., Bresch, H., Engel, G., Rosner, H., Majeurs, P., Scheurer, R., Bodechtel, C.C., 2001. The German ochratoxin A 
project: contamination of foods and consumer exposure. Mycotoxins $51,31-35$.

Grosso, F., Said, S., Mabrouk, I., Fremy, J.M., Castegnaro, M., Jemmali, M., Dagracci, S., 2003. New data on the occurrence of ochratoxin A in human sera from patients affected or not by renal diseases in Tunisia. Food Chem. Toxicol. 41, 1133-1140.

Hald, B., 1991. Ochratoxin A in human blood in European countries in mycotoxins, endemic nephropathy and urinary tract tumors. IARC $115,159-164$.

Hassen, W., Abid, S., Achour, A., Creppy, E., Bacha, H., 2004. Ochratoxin $A$ and $\beta_{2}$-microglobulinuria in healthy individuals and chronic interstitial nephropathy patients in the Centre of Tunisia: a hot spot of ochratoxin A exposure. Toxicology 199, 185-193.

Hill, A.R.C., Reynolds, S.L., 1999. Guidelines for in-house validation of analytical methods for pesticide residues in food and animal feeds. Analyst 124, 953-958.

Hubner, L., 1998. Validation of analytical methods: review and strategy. LC-GC Int. 11, 96-105.

IARC Monographs on the evaluation of carcinogenic risks of chemicals to humans. 1993, vol. 56: Some naturally occurring substances: some food items and constituents, heterocyclic aromatic amines and mycotoxins. IARC, Lyon.

Jimenez, A.M., Cerain, A.L., González-Penas, E., Bello, J., Betbeder, A.M., Creppy, E.E., 1998. Exposure to ochratoxin A in Europe: comparison with a region of northern Spain. J. Toxicol.-Toxin Rev. 17, 479-491.

Kane, A., Diop, N., Diack, T.S., 1991. Natural occurrence of ochratoxin A in food and feed in Senegal. IARC Monographs on mycotoxins, endemic nephropathy and urinary tract tumours. IARC, 93-96.

Leitner, A., Zoller, P., Paolill, O.A., Stroka, J., Papadopoulou-Bouraoui, A., Jaborek Anklam, E., Lindner, W., 2002. Comparison of methods for the determination of ochratoxin A in wine. Anal. Chim. Acta 453, 33-41.

Marquardt, R.R., Frolich, A.A., 1992. A review of recent advances in understanding ochratoxicosis. J. Anim. Sci. 70, 3968-3988.

Moreno Guillamont, E., Lino, C.M., Baeta, M.L., Pena, A.S., Silveira, M.I.N., Mañes, J., 2005. A comparative study of extraction apparatus in HPLC analysis of ochratoxin A in muscle. Anal. Bioanal. Chem. $383,570-575$.

Palli, D., Miraglia, M., Saieva, C., Masala, G., Cava, E., Colatosti, M., Corsi, A.M., Russo, A., Brera, C., 1999. Serum levels of ochratoxin A in healthy adults in Tuscany: correlation with individual characteristics and between repeat measurements. Cancer Epidem. Biom. Prevent 8, 265-269.
Pena, A., Cerejo, F., Lino, C.M., Silveira, M.I., 2005. Determination of ochratoxin A in portugueses rice samples by high performance liquid chromatography with fluorescence detection. Anal. Bioanal. Chem. 382, 1288-1293.

Pena, A., Seifrtova, M., Lino, C., Silveira, I., Solich, P., 2006. Estimation of ochratoxin A in Portuguese population: new data on the occurrence in human urine by high performance liquid chromatography with fluorescence detection. Food Chem. Toxicol. 44, 1449-1454.

Peraica, M., Domijan, A.-M., Fuchs, R., Lucic, A., Radic, B., 1999. The occurrence of ochratoxin A in blood in general population of Croatia. Toxicol. Lett. 110, 105-112.

Peraica, M., Domijan, A.-M., Matasin, M., Lucic, A., Radic, B., Delas, F., Horvat, M., Bosanac, I., Balija, M., Grgicevic, D., 2001. Variations of ochratoxin A concentration in the blood of healthy populations in some Croatian cities. Arch. Toxicol. 75, 410-414.

Petkova-Bocharova, T., Castegnaro, M., Pfohl-Leszkowicz, A., Garren, L., Grosso, F., Nikolov, I., Vrabcheva, T., Dragacci, S., Chernozemsky, I.N., 2003. Facta Univer. 10, 62-68.

Scott, P.M., Kanhere, S.R., Lau, B.P.-Y., Lewis, D.A., Hayward, S., Kuiper-Goodman, T., 1998. Survey of Canadian human blood plasma for ochratoxin A. Food Addit. Contam. 15, 555-562.

Singare-Tigori, B., Moukha, S., Kouadio, J.H., Dano, D.S., Betbeder, A.M., Achour, A., Creppy, E.E., 2006. Ochratoxin A in human blood in Abidjan, Côte d'Ivoire. Toxicon 47, 894-900.

Swartz, M.E., Krull, I.S., 1998. Validation of chromatographic methods. Pharma. Tech. 22, 104-120.

Thuvander, A., Paulsen, J.E., Axberg, K., Johansson, N., Vidnes, A., Enghardt-Barbieri, H., Trygg, K., Lund-Larsen, K., Jahrl, S., Widenfalk, A., Bosnes, V., Alexander, Y., Hult, K., Olsen, M., 2001. Levels of ochratoxin A in blood from Norwegian and Swedish blood donors and their possible correlation with food consumption. Food Chem. Toxicol. 39, 1145-1151.

Valenta, H., 1998. Chromatographic methods for the determination of ochratoxin A in animal and human tissues and fluids. J. Chromatogr. A $815,72-92$.

Visconti, A., Pascale, M., Centonze, G., 2000. Determination of ochratoxin $\mathrm{A}$ in domestic and imported beers in Italy by immunoaffinity clean-up and liquid chromatography. J. Chromatogr. A 888, 321-326.

Zimmerli, B., Dick, R., 1995. Determination of ochratoxin A at ppb level in human blood, serum, milk and some foodstuffs by HPLC with enhanced fluorescence detection and immunoaffinity column cleanup: methodology and Swiss data. J. Chromatogr. B Biomed. Appl. 666, 85-99. 